\title{
Smuts Finger Grass (Digitaria Eriantha Cv Irene) Root Growth Assessment and Some Physicochemical Characteristics on Coal Mined Land Compacted Soil
}

\author{
*MOSEBI, PE; TRUTER, WF; MADAKADZE, IC \\ Department of Plant Production and Soil Science, University of Pretoria, Pretoria, 0002 \\ *Corresponding Author Email: pe.mosebi@nul.ls
}

\begin{abstract}
The coal mine soil layers contained high values of bulk density of $1.80 \mathrm{gcm}^{-3}$ and $1.90 \mathrm{gcm}^{-3}$ at depths of 0-20 and 20-40 cm respectively, low contents of organic matter, soil $\mathrm{pH}$ and soil nutrients concentration. A field trial was conducted to investigate root growth responses of Smuts Finger grass (Digitaria eriantha cv Irene) to compacted mine soil layers. It was revealed that the greatest root masses were noted in the upper horizons with progressively significantly less in the deeper horizons. Roots of this species penetrated compacted soil layers and decreased soil bulk density. The highest soil $\mathrm{pH}$ values were found in the upper layers with greatest root biomass. Soil nutrients $(\mathrm{P}, \mathrm{Mg}, \mathrm{Ca}, \mathrm{Na}$ and $\mathrm{K}$ ) status was also better in the upper layers. Smuts Finger grass could be used as an alternative method for rehabilitation of compacted mine soil layers.
\end{abstract}

\section{DOI: https://dx.doi.org/10.4314/jasem.v22i8.24}

Copyright: Copyright (C) 2018 Mosebi et al. This is an open access article distributed under the Creative Commons Attribution License (CCL), which permits unrestricted use, distribution, and reproduction in any medium, provided the original work is properly cited.

Dates: Received: 09 July 2017; Revised: 23 July: 2018; Accepted: 27 August 2018

Keywords: Coal mine soil; Smuts Finger grass; Soil bulk density; Soil pH; Soil nutrients

Returning mined land to productivity through reclamation activities requires more time than other stages of site construction and mining (Adiansyah et al., 2015). Process of restoring surface environment to acceptable pre-existing condition includes various approaches such as surface contouring and revegetation. Technical approaches of reclamation activities often aim to manage a mined area for specific natural value or agricultural activities or other human uses. Where other human uses are planned, mined area is shaped in a manner that it would allow future infrastructure development (Edraki et al., 2014). Reclamation activities to return mined areas to a more natural state focus on soil, wildlife, water and vegetation management values. Agricultural activities target livestock, grassland and forestry production (Kavamura \& Esposito, 2010). Reclamation activities that may cause environment impacts include heavy vehicle traffic during filling in the mine, removal of infrastructure and land re-contouring (Pan et al., 2014). In coal mined areas, soil compaction is very important problem. Compaction increased the bulk density and strength of soil. Coal mine soil layers contain high values of bulk density of $1.80 \mathrm{gcm}^{-3}$ and $1.90 \mathrm{gcm}^{-3}$ at depths of $0-20$ and $20-40 \mathrm{~cm}$ respectively. Compaction resulted to reduced circulation of air and water in soil leading to poor plant growth. Compaction has reduced ground coverage and enhanced erosion. Impacts of soil erosion include soil nutrient loss and reduced water quality in nearby surface water bodies
(Shahgholi et al., 2015). Soil compaction can be maintained or improved through various management strategies. Using self-sustaining plant cover which includes grass species that vary in rooting depth and type help to minimize soil compaction impacts (Kaliyan, et al., 2013). Grass species with good root systems help in several ways. Plant roots grow through and break compacted soil aggregates. Plant cover improves soil structure, water infiltration by creating root channels and penetration into soil (Wick et al., 2017). Both roots and vegetative cover increase organic matter and recycle soil nutrients, which improve compacted soil particles. Grass species promote biological diversity by improving aggregate stability through root entanglement around soil particles and root secretion, which act as glues to hold soil particles together (Stumpf et al., 2016).

Morphological characteristics of Smuts Finger grass (Digitaria eriantha cv Irene) makes it suitable to grow on extreme soils and climatic conditions. It is well reported that being vegetative it is environmental friendly and very effective in slowing and spreading runoff water, reducing soil erosion and conserving soil moisture (Homma et al., 2012). Some previous studies on Smuts Finger grass have elaborated the root morphological characteristics. Deep and massive thick root system of Smuts Finger grass binds soil. The root properties can help improve aggregate stability of disturbed soil. This very deep growing root system

*Corresponding Author Email: pe.mosebi@nul.ls 
enhances slope stability when properly planted on soil slopes (Chen et al., 2014). Deep root system makes Smuts Finger grass extremely drought tolerant (Lindh et al., 2014). The root penetration is mainly vertical and grows up to $2 \mathrm{~m}$ deep depending on the soil conditions (Alcantara et al., 2015). Based on these characteristics Smuts Finger grass is being used in a range of disturbed areas. This study was conducted to assess root growth of Smuts Finger grass on compacted soil and to see their potential for improved bulk density in order to have a better understanding of soil compaction tolerance. In addition, investigate $\mathrm{pH}$ $\left(\mathrm{H}_{2} \mathrm{O}\right)$ and nutrients concentration in the compacted soil.

\section{MATERIALS AND METHODS}

Site description: The field trial was located on a surface coal mine planted to Smuts Finger grass (5 years old) in Mpumalanga Province in South Africa in between Latitude $26^{\circ} 28^{\prime} \mathrm{S}$ and Longitude $28^{\circ} 75^{\prime} \mathrm{E}$. The average annual temperature was $30.4{ }^{\circ} \mathrm{C}$ and annual rainfall was $750 \mathrm{~mm}$. This site is at a altitude of 1570 $\mathrm{m}$ above sea level. The area of the field trial was 20 ha. The soil comprised a mixture of sandy clay A and a silty loam B horizons. The main characteristics of this cover soil were $11.5 \%$ clay, $12.9 \%$ silt and $67.8 \%$ sand. The Smuts Finger grass (D. eriantha cv Irene) was established on rehabilitated dryland, which had been identified as compacted mine land. The bulk density of cover mine soil varied from $1.80 \mathrm{gcm}^{-3}$ to $1.90 \mathrm{gcm}^{-3}$ at depths of $0-20$ and $20-40 \mathrm{~cm}$ respectively.

Experimental layout: The root biomass, bulk density, $\mathrm{pH}\left(\mathrm{H}_{2} \mathrm{O}\right)$ and soil nutrients concentration were collected from compacted soil depth. The treatments were composed of 0-10, 10-20, 20-30 and 30-40 cm on two sites Upland and Lowland. At each site, observations were replicated five times over a representative 0.5 ha. The total area of the field was 20 ha. The Upland site was identified as the area with a higher elevation and the Lowland site was the area with a lower elevation.

Root sampling and analysis: Root samples of Smuts Finger grass were collected in the first and second growing seasons (February to April and October to December). The soil coring method used to sample the roots was implemented by inserting a root augur having a diameter of $20 \mathrm{~cm}$, to depths of $0-10,10-20$, 20-30 and 30-40 cm. The root mass at each depth was determined by dispersing the soil sample in water and subsequently retrieving the floating roots on a $250 \mu \mathrm{m}$ sieve. The root dry mass was measured using a Sartorius scale after samples had been dried in an oven at $65^{\circ} \mathrm{C}$ for 72 hours.
Bulk Density: Penetrometer cone was inserted into the soil at 0-10, 10-20, 20-30 and 30-40 cm depth. At each depth measurements were taken and used for calibration. The calibration data were fitted to wave software that was used to show calibration curve, which allows determination of density values.

Soil sampling and analysis: Soil samples were collected from the same location as the root samples. Soil samples at 0-20 and 20-40 cm were collected during each growing season to analyse for $\mathrm{pH}\left(\mathrm{H}_{2} \mathrm{O}\right)$ and nutrient concentrations $(\mathrm{P}, \mathrm{Ca}, \mathrm{K}, \mathrm{Mg}$ and $\mathrm{Na}$ $\mathrm{mgkg}^{-1}$ ) using an ammonium acetate extraction method.

Statistical analysis: Data were analysed statistically and the significant differences between different treatments were determined using SAS (SAS Inst., 2004). Least significant difference (LSD) mean separation test at $\mathrm{P} \leq 0.05$ was used where significant differences occurred.

\section{RESULTS AND DISCUSSION}

Root biomass: The root biomass of Smuts Finger grass in four soil layers, at both Lowland and Upland sites in the first and second growing seasons is illustrated in Table 1. In the first season, the highest root biomass was in the $0-10 \mathrm{~cm}$ soil layer followed by the $10-20 \mathrm{~cm}$ soil layer, then the $20-30$ and $30-40 \mathrm{~cm}$ soil layers. By the second season, the root biomass in all layers had increased markedly. The greatest root masses were noted in the $0-10 \mathrm{~cm}$ horizon with progressively significantly less in the deeper horizons. This might have been due to differences in rainfall between the two seasons. In a good rainfall season (second season) roots penetrated much deeper, while in a bad season (first season) the roots were restricted, being concentrated mainly in the topsoil. Plant species differ considerably in their ability to distribute their roots (Tow et al., 1997).

Table 1: Smuts Finger grass root biomass at different sites over two growing seasons

\begin{tabular}{lcrc}
\hline Seasons & $\begin{array}{c}\text { Soil depth } \\
\text { cm }\end{array}$ & Upland & $\begin{array}{c}\text { Lowland } \\
\mathbf{k g h a}^{-1}\end{array}$ \\
\hline $1^{\text {st }}$ Season & $0-10$ & $3534.04^{\mathbf{A}}$ & $3344.91^{\mathbf{A}}$ \\
& $10-20$ & $1556.53^{\mathbf{B}}$ & $1565.49^{\mathbf{B}}$ \\
& $20-30$ & $406.05^{\mathbf{C}}$ & $49.84^{\mathbf{C}}$ \\
& $30-40$ & $243.83^{\mathbf{C}}$ & $46.82^{\mathbf{C}}$ \\
& SE \pm & 1.02 & 1.07 \\
$2^{\text {nd }}$ Season & $0-10$ & $5464.77^{\mathbf{A}}$ & $7093.95^{\mathbf{A}}$ \\
& $10-20$ & $4064.49^{\mathbf{B}}$ & $4923.37^{\mathbf{B}}$ \\
& $20-30$ & $3913.22^{\mathbf{B}}$ & $3854.5^{\mathbf{B C}}$ \\
& $30-40$ & $3604.70^{\mathbf{B}}$ & $3427.55^{\mathbf{C}}$ \\
& $\mathrm{SE} \pm$ & 1.34 & 1.42 \\
\hline
\end{tabular}

* ${ }^{\mathrm{ABC}}$ superscript values in the same season column followed by a different letter are significantly different according to Duncan's test at the $\mathrm{P}$ value $\leq 0.05$. S.E. is the standard error. 
A study in Vetiver suggested that higher density of roots in the soil layers may be associated with an increased rainfall (Le Bot et al., 2010).

Soil bulk density: Bulk density of mine soil planted to Smuts Finger grass increased with soil depth on both Upland and Lowland sites (Figure 1). At these sites, the lowest bulk density was recorded in $0-10 \mathrm{~cm}$ soil depth, followed by $10-20 \mathrm{~cm}, 20-30 \mathrm{~cm}$ and it was highest in the $30-40 \mathrm{~cm}$ soil depth. This lower bulk density in the upper layers might be due to the increased root growth of Smuts Finger grass. It has been reported that increased root growth and activity improves soil aggregation, decreases soil bulk density when large quantities of organic material are supplied to soils from roots (Haynes \& Naidu, 1998). Fitter (1996) also reported that living roots, through normal growth and senescence of root segments and root hairs, may exert great forces on soil and might then have the ability to penetrate compacted soil.

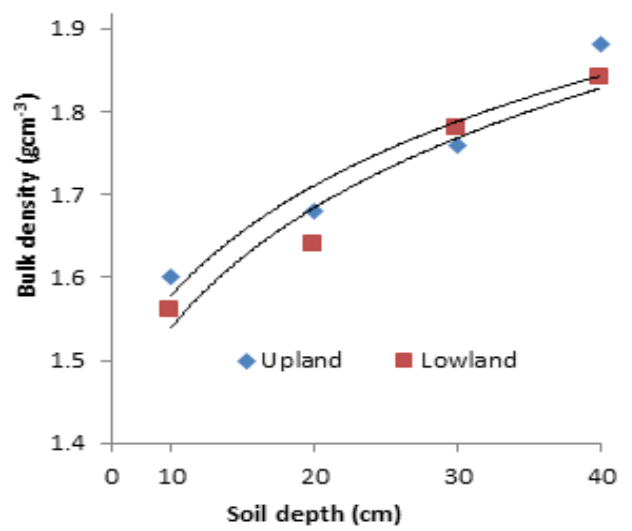

Fig. 1: Soil bulk density at different soil depths on Upland and Lowland sites planted to Smuts Finger grass. Equations provided are logarithmic regressions.
Soil $\mathrm{pH}\left(\mathrm{H}_{2} \mathrm{O}\right)$ : The soil $\mathrm{pH}\left(\mathrm{H}_{2} \mathrm{O}\right)$ at different depths from Upland and Lowland site is presented in Figure 2. In Upland site, the soil $\mathrm{pH}\left(\mathrm{H}_{2} \mathrm{O}\right)$ ranged between 4.15 and 5.62. The soil $\mathrm{pH}\left(\mathrm{H}_{2} \mathrm{O}\right)$ of Lowland site ranged between 4.96 and 5.74. At these sites the highest soil $\mathrm{pH}$ values were found at $0-10$, followed by $10-20 \mathrm{~cm}, 20-30 \mathrm{~cm}$ and the lowest at $30-40 \mathrm{~cm}$. This might be the available root biomass in upper layers than lower layers. In other studies it was reported that roots have the buffering effect for changing soil pH (Maiti \& Ghose, 2005; Li 2006). Plant roots raised soil $\mathrm{pH}$ by absorbing mobile heavy metals (Lone et al., 2008). As plant roots add organic matter in soil textural class, soil $\mathrm{pH}$ increases significantly (Moreno-de las et al., 2008).

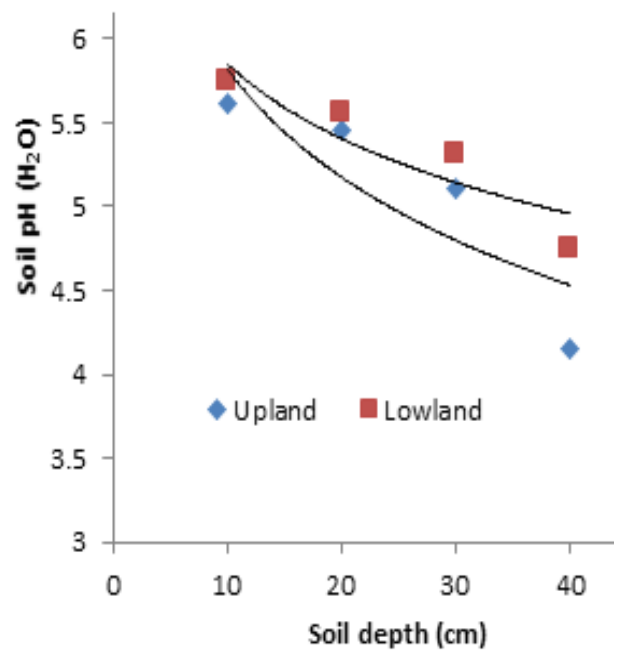

Fig. 2: Soil $\mathrm{pH}\left(\mathrm{H}_{2} \mathrm{O}\right)$ at different soil depths on Upland and Lowland sites planted to Smuts Finger grass. Equations provided are logarithmic regressions.

Table 2: Nutrient concentrations in the compacted mine soil planted to Smuts Finger grass on the Upland and Lowland site.

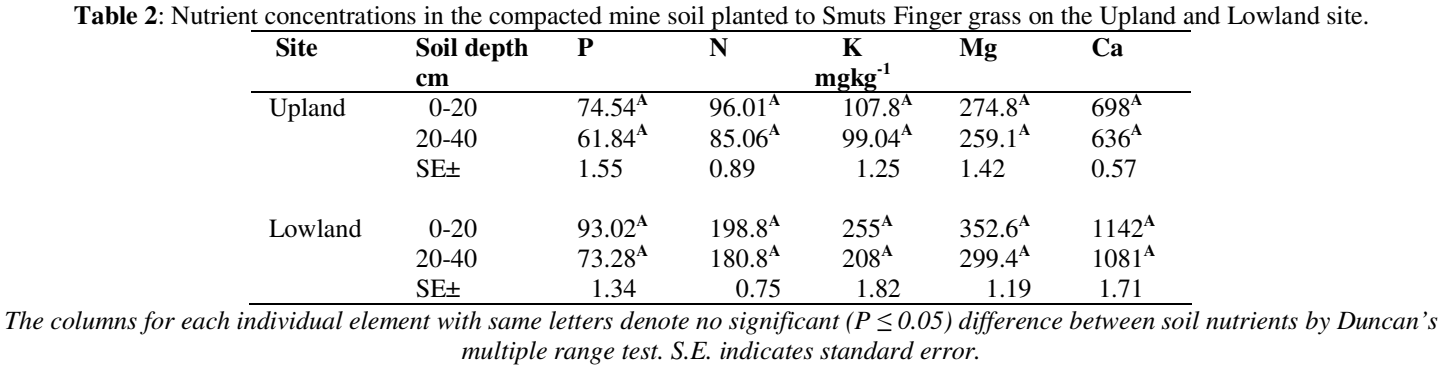

Soil nutrients concentration: Soil nutrients $(\mathrm{P}, \mathrm{Mg}, \mathrm{Ca}$, $\mathrm{Na}$ and $\mathrm{K}$ ) concentration were statistically similar in both at 0-20 and 20-40 $\mathrm{cm}$ soil depths on both Upland and Lowland site (Table 2), although, there was a tendency that the nutrient status was better in the upper layers. This might be ascribed to accumulation of organic matter and highly developed roots of Smuts Finger grass into upper layers as compared to lower layers. In another study, investigating the influence of the level of soil fertility on the botanical composition of pastures established on rehabilitated strip-mined land in South Africa, high soil nutrients concentration 
was found around Smuts Finger grass rooting depth (Rethman and Tanner, 1993). Metalliferous soils in the Bo Ngam lead mine area planted to grass species had the highest soil nutrients at $0-20 \mathrm{~cm}$ soil depths (Rotkittikhun et al., 2006).

Conclusion: Smuts Finger grass showed the best growth in compacted soil layers. The greatest root masses were noted in the upper horizons with progressively significantly less in the deeper horizons. Smuts Finger grass was good choice for improving of compacted mine soils. Smuts Finger grass showed very high tolerance to high bulk density and increased root growth to penetrate compacted soil layers. In addition, the use of Smuts Finger grass also resulted in improved soil $\mathrm{pH}$ and increased soil nutrient concentrations. This species was considered more suitable for improving mine soil condition and the danger of compacted soil layers became minimal.

Acknowledgments: The authors would like to acknowledge the Coaltech project and the University of Pretoria for financial support of this study. We would also like to thank Shaun for help with soil sample preparation and analysis.

\section{REFERENCES}

Adiansyah, JS; Rosano, M; Vink, S; Keir, G (2015). A Framework for a Sustainable Approach to Mine Tailings Management: Disposal Strategies. J. Clean. Prod. 108: 1050-1062.

Alcantara, HJ; Doronila, AI; Nicolas, M; Ebbs, SD; Kolev, SD (2015). Growth of Selected Plant Species in Biosolids-Amended Mine Tailings. Miner. Eng. 80: 025-032.

Chen, YL; Palta, J; Clements, J; Buirchell, B; Rengel, Z (2014). Root Architecture Alteration of Perennial and Annual Grasses in Response to Soil Compaction. Fiel. Crop. Res. 165: 061-070.

Edraki, M; Baumgartl, T; Manlapig, E; Bradshaw, D; Franks, D (2014). Designing Mine Tailings for Better Environmental, Social and Economic Outcomes: a Review of Alternative Approaches. J. Clean. Prod. 84: 411-420.

Fitter, A (1996). Characteristics and Functions of Root Systems. In: Waisel, Y; Eshel, A; Kafkafi, U (eds) Plant Roots - The Hidden Half. Marcel Dekker, Inc., New York, p.111-126.

Haynes, RJ; Naidu, R (1998). Influence of Lime, Fertilizer and Manure Applications on Soil Organic Matter Content and Soil Physical Conditions: A Review. Nut. Cyc. Agro Eco. 51: 123-137.

Homma, SK; Tokeshi, H; Mendes, LW; Tsai, SM (2012). Long-term Application of Biomass and Reduced use of Chemical Alleviate Soil Compaction and Improve Soil Quality. Soil Till. Res. 120: 147-153.
Kaliyan, N; Morey, RV; Schmidt, DR (2013). Roll Press Compaction of Corn Stover and Perennial Grasses to Increase Bulk Density. Bio. Bioenergy. 55: 322-330.

Le Bot, J; Serra, V; Fabre, J; Draye, X; Adamowicz, S; Pages, L (2010). DART: a Software to Analyse Root System Architecture and Development from Captured Images. Plant Soil. 326: 261-273.

Li, MS (2006). Ecological Restoration of Mine Land with Particular Reference to the Metalliferous Mine Wasteland in China: a Review of Research and Practice. Soil Tot. Environ. 357: 038-053.

Lindh, M; Zhang, L; Falster, D; Franklin, O; Brannstrom, A (2014). Plant Diversity and Drought: The Role of Deep Roots. Ecol. Model. 290: 085-093.

Lone, MI; He, ZL; Stoffella, PJ; Yang, X (2008). Phytoremediation of Heavy Metal Polluted Soils and Water: Progress and Perspectives. J. of Zhe.Univ.Sci. 9(3): 210-220.

Maiti, SK; Ghose, MK (2005). Ecological Restoration of Acidic Coal Mine Overburden Dumps- an Indian Case Study. La. Contam. Recl.13 (4): 361-369.

Moreno-de las, HM; Nicolau, JM; Espigares, MT (2008). Vegetation Succession in Reclaimed Coal Mining Sloped in a Mediterranean-Dry Environment. Eco. Eng. 34: 168-178.

Pan, H; Zhou, G; Cheng, Z; Yang, R; He, L; Zeng, D; Sun, B (2014). Advances in Geochemical Survey of Mine Tailings Project in China. J. Geochem. Explor. 139: 193-200.

Rethman, NFG, Tanner, PD (1993). The Influence of Level of Soil Fertility on the Botanical Composition of Pastures Established on Rehabilitated Strip-Mined Land in South Africa. Presentation at the $10^{\text {th }}$ National Meeting of the American Society for Strip Mining \& Reclamation, Spokane, Washington.

Rotkittikhun, P; Kruatrachue, M; Chaiyarat, R; Ngernsansaruay, C; Pokethitiyook, P; Paijitprapaporn, A; Baker, A (2006). Uptake and Accumulation of Lead by Plants from the Bo Ngam Lead Mine Area in Thailand. Envir. Pol. 144: 681688.

SAS Institute Inc (2004). The SAS System for Windows. SAS Institute Inc. SAS Campus Drive, Cary, North Carolina, USA.

Shahgholi, G; Abuali, M (2015). Measuring Soil Compaction and Soil Behavior Under the Tractor Tire Using Strain Transducer. J. Terramech. 59: 019025.

Stumpf, L; Pauletto, EA; Pinto, LS (2016). Soil Aggregation and Root Growth of Perennial Grasses in a Constructed Clay Mine Soil. Soil Till. Res. 161: 071078.

Tow, PG; Lazenby, A; Lovett, JV (1997). Adaptation and Complementarity of Digitaria Eriantha and Medicago Sativa on a Solodic Soil in a Subhumid Environment with Summer and Winter Rainfall. Aust. J. Exp. Agric. 37: 311-322.

Wick, A; Berti, M; Lawley, Y; Liebig, M (2017). Integration of Annual and Perennial Cover Crops for Improving Soil Health. Soil Healt. Intensif. Agro. 18: 127-135. 